\title{
Value-saturated Education in Erzsébet Camps in Zánka, Hungary ${ }^{1}$
}

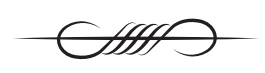

\begin{abstract}
The Erzsébet Camp in Zánka is located in the Balaton Highland, between Tihany and Badacsony. The Erzsébet Camps are one of the largest youth-project program in Hungary. Research data collection started in 2017, and it was carried out in three periods. The present study conducted analyses on a database compiled from findings of questionnaires administered to campers (2017, 2018 and 2019) and their chaperones (2018 and 2019). Data collection from the children and chaperones took place at the end of each camp shift and comprised of self-administered anonymous questionnaires with ten question blocks. The study conducts analyses of the database compiled from the main answers of more than 18,000 participants. Our research, exploratory in its nature, set out to compile the "value map" of the Erzsébet Camps. The main focus of our interest was the added value and developmental effects of the camps with respect to campers. The another research question was what social values are transmitted and the preservation of which social values is supported by the Erzsébet Camps.
\end{abstract}

\section{KEYWORDS}

children and youth, summer camp, leisure-time pedagogy, social values, social skills

DOI 10.14232/belv.2020.3.3

https://doi.org/10.14232/belv.2020.3.3

Cikkre való hivatkozás / How to cite this article:

Jancsák, Csaba (2020): Value-saturated Education in Erzsébet Camps in Zánka, Hungary. Belvedere Meridionale vol. 32. no. 3. 31-46. pp 
ISSN 1419-0222 (print)

ISSN 2064-5929 (online, pdf)

(Creative Commons) Nevezd meg! - Így add tovább! 4.0 (CC BY-SA 4.0)

(Creative Commons) Attribution-ShareAlike 4.0 International (CC BY-SA 4.0)

www.belvedere-meridionale.hu

\section{INTRODUCTION}

The Erzsébet Camp in Zánka is located in the picturesque surroundings of the Balaton Highland, between Tihany and Badacsony, on an area of 100 hectares. The institution was named after the daughter of the Hungarian king Andrew II, Princess St. Elizabeth (1207-1231), who gave alms to those in need, founded institutions for orphans and built hospitals for the poor. With its enormous green area, the camp is adjacent to the shore of Balaton lake and has its own port, a railway station, several sports fields, an adventure park, concert venues and a cinema. The Erzsébet Camps are the largest camping program in Hungary, which is run by the Erzsébet Foundation for Children in the Carpathian Basin. The Foundation's documents and its website both declare that their most important mission to create a supportive environment, which is manifested through experiential pedagogy and recreational events, a methodologically sound development space and events that provide safe and high-quality services for children.

The methodological objectives of the camps (BADEN-Powell 1908, 1992; SíK 1992, MAJZIK 1997; BÁNHIDI 2004; BODOR 2006; DoRKa é.n.; HEIMANN 2006; NAGY 2018; SOLYMOSI 2020; TRENCSÉNYI 2018) focus on active recreation and personality development, so sports activities, popular science programs, cultural heritage programs, decent entertainment and the representation of Christian social values play an important role in the educational program. The Erzsébet Camps consider it their mission to promote a healthy way of life, self-awareness, tolerance towards people living with disabilities, the development of trust in each other and sensitisation and education for the protection of our natural environment. The programs in the camp focus on gaining experiences. Disadvantaged children, children in residential care, children with special needs and children living with disabilities receive special attention in the camps. The six-day and five-night "sleepover" summer "Experience Camps", aiming at creating equal opportunities, have been realized by Hungarian budget support and EU funding since 2017. Due to the financial support, it is mostly children from the less developed regions of Hungary that can participate in the camping program. In the implementation of the programs, special attention is paid to disadvantaged and highly disadvantaged children, children supported by child welfare services and children with special needs. The present study presents our research findings on the Erzsébet Camps in Zánka, which provide camping opportunities for nearly 25,000 children. 


\section{ReSEARCH METHODOLOGY}

Data collection started in 2017, and it was carried out in three periods. Data collection from the children took place at the end of each camp shift and comprised of self-administered anonymous questionnaires with ten question blocks. This study conducts analyses of the database compiled from the main answers of more than 18,000 participants. The distribution of children participating in the survey in each year is presented in Table 1. This element of the research aimed at gaining a deeper understanding of the children's attitudes towards the camps, who are the direct target group of the Erzsébet Camps. The questionnaire examined the attitudes as they developed during the camping experience, as well as the evaluation of both the whole program and specific elements of the program. The distribution of participants by camp shifts is shown in the table below.

\begin{tabular}{|c|c|c|c|c|c|c|c|c|c|c|c|c|}
\hline Turnusok & $\mathbf{1}$ & $\mathbf{2}$ & $\mathbf{3}$ & $\mathbf{4}$ & $\mathbf{5}$ & $\mathbf{6}$ & $\mathbf{7}$ & $\mathbf{8}$ & $\mathbf{9}$ & $\mathbf{1 0}$ & $\mathbf{1 1}$ & SUM \\
\hline 2017 & 178 & 277 & 371 & 425 & 391 & 450 & 344 & 409 & 263 & 346 & - & 3454 \\
\hline 2018 & 289 & 222 & 285 & 180 & 297 & 358 & 297 & 312 & 349 & 333 & 255 & 3177 \\
\hline $\mathbf{2 0 1 9}$ & 962 & 1113 & 1208 & 1065 & 1399 & 1521 & 1310 & 1332 & 740 & 560 & 552 & $\mathbf{1 1 7 6 2}$ \\
\hline $\mathbf{2 0 1 9}(\boldsymbol{\%})$ & 8.2 & 9.5 & 10.3 & 9.1 & 11.9 & 12.9 & 11.1 & 11.3 & 6.3 & 4.8 & 4.7 & $\mathbf{1 0 0}$ \\
\hline
\end{tabular}

TABLE 1 Number of participants

$55 \%$ of the participants were girls (60.6\% in 2018 and $61 \%$ in 2017$)$ and $45 \%$ were boys (39.4\% in 2018 and 39\% in 2017). Girls were slightly over-represented among the respondents in all the shifts.

As far as the age distribution of the participants is concerned, it is revealed that it was mostly children in their early puberty period, i.e. the 10 to 14 age group, that make up $82-84 \%$ of the campers in each year. (Figure 1).

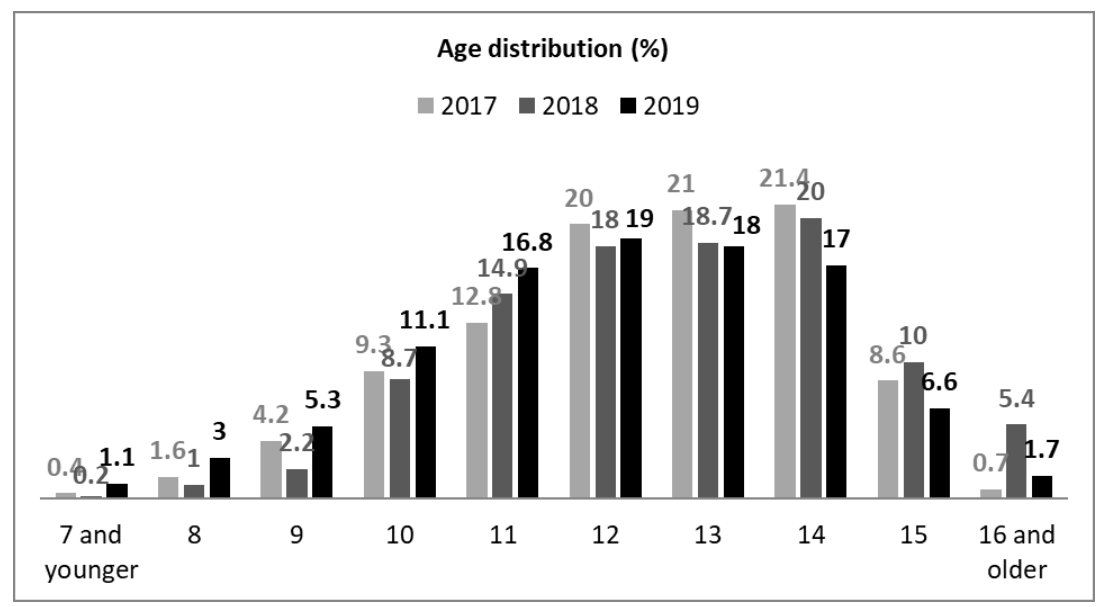

Figure 1 
When preparing the present study, two further analyses were conducted on the same database. Data collection from chaperons was also carried out at the end of each camp shift from 2017 onwards. The chaperones were asked to take part in anonymous self-administered questionnaires, consisting of 10 question blocks (Table 2). Based on our database containing 2,896 participants' responses, we examined what added value the camps represent in children's and teachers' lives according to the chaperones' opinions.

\begin{tabular}{|c|c|c|}
\hline 2017 & 2018 & 2019 \\
\hline 503 & 935 & 1431 \\
\hline
\end{tabular}

TABLE 2 Chaperones participating in the survey (persons)

In the winter of 2018, we conducted another survey focusing on the developmental effects of the camps as reflected by the chaperones' opinions. The online questionnaire was completed by 357 people, 329 of them being teachers. The aim of data collection was to investigate the chaperones' views (not so much their attitudes immediately after the camp but their more "settled" assessment on the practical value of the camps) on the more distant impact of the camps. The presupposition was that opportunities for educational and developmental effects of the camps could manifest themselves in the autumn among children and groups of children who had participated in a camp during the summer. This practical experience would shape and consolidate the chaperones' views on the camps. The average teaching experience of the respondents was 23 years, and most of them had spent 20 years in the teaching profession. The majority of respondents started their teaching career more than 10 years before, 9\% had 5-10 years of teaching experience and $5 \%$ had less teaching experience than that.

\section{Added Value of THe CAMPS}

\subsection{Children's views on the programs and program elements.}

A highly important element of recreational education services are those content elements that determine its microclimate: events with added values, enriching participants' personality by sensitising them with the help of experiential pedagogy. These events do not only provide recreational and flow experiences and develop competencies but also contribute to children "having a good time". The participants in the "sleepover" camps in Zánka in 2019 gave highly positive feedback on the related question. (Figure 2) Two thirds of the children had a very good time during the camp programs. A quarter of the campers were characterized by having a good time (rather good, 4 on the scale). Altogether, the two response categories ( 5 and 4 on the scale) were chosen by $89 \%$ of the respondents. $3.4 \%$ of the campers indicated that they did not have a good time during the programs in the camp. The data suggest that the greatest strength of the camps is the experience element of the programs. The mean scores of the responses on the 5-point scale in the three waves of data collection show that the campers were satisfied with the experiences in all three years of the study. (Table 3) 


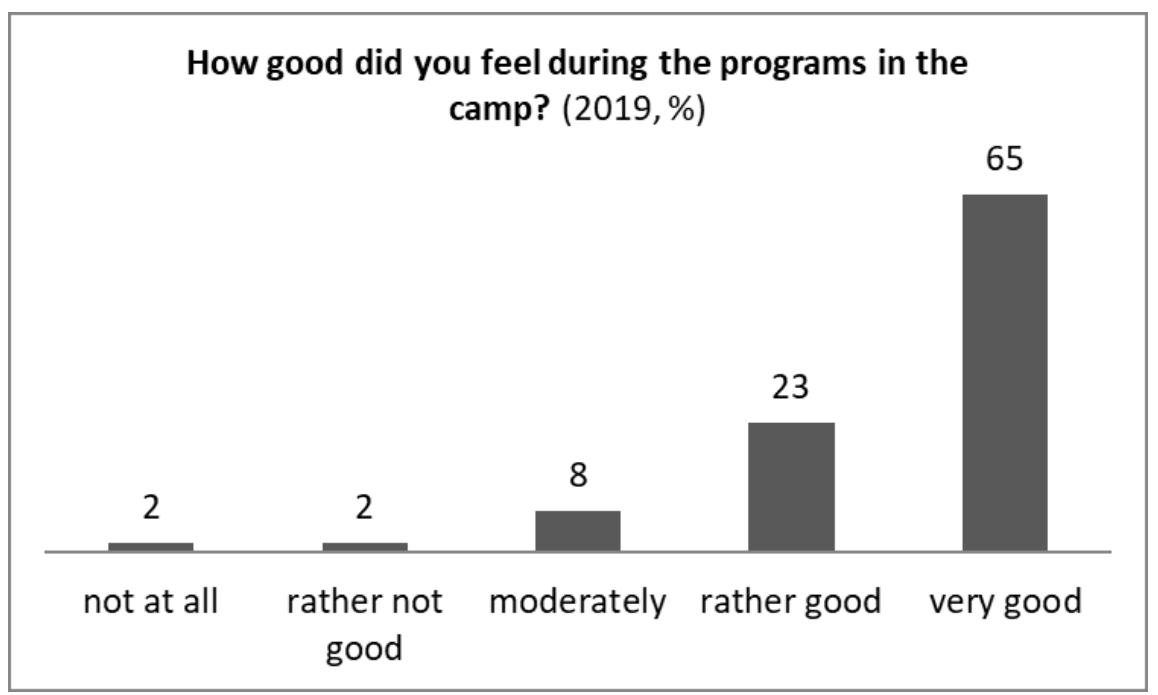

Figure 2

\begin{tabular}{|c|c|c|}
\hline 2017 & 2018 & 2019 \\
\hline 4.4 & 4.6 & 4.5 \\
\hline
\end{tabular}

TABLE 3 How good did you feel during the programs in the camp?

(mean scores on 5-point scale)

The study investigated which factors of each program element support and reinforce the mission of the camp. We investigated this issue with reference to fifteen factors. The mean values of realized program elements within each set of program elements were summarized. Table 4 reveals that it was program complexes in the field of social and community competences and healthy lifestyle and culture that received the highest mean scores based on children's responses.

\begin{tabular}{|l|c|c|}
\hline & $\begin{array}{c}\text { number of } \\
\text { program } \\
\text { elements } \\
\text { (pcs) }\end{array}$ & $\begin{array}{c}\text { mean } \\
\text { score on } \\
5 \text {-point } \\
\text { scale }\end{array}$ \\
\hline $\begin{array}{l}\text { Organizing programs and meetings for children arriving from } \\
\text { different places and environment, which aim at providing common } \\
\text { experiences and facilitate understanding each other. }\end{array}$ & 22 & 4.44 \\
\hline $\begin{array}{l}\text { Programs aiming at community skills, self-acceptance, effective } \\
\text { communication with peers and building trust. }\end{array}$ & 22 & 4.38 \\
\hline
\end{tabular}




\begin{tabular}{|l|c|c|}
\hline $\begin{array}{l}\text { Developing social competences through experiential learning in } \\
\text { groups. }\end{array}$ & 21 & 4.33 \\
\hline $\begin{array}{l}\text { Encouraging children's initiative skills, creativity and resourceful- } \\
\text { ness. }\end{array}$ & 18 & 4.44 \\
\hline $\begin{array}{l}\text { Developing children's health conscious behaviour and physical } \\
\text { activity, mastering first aid skills. }\end{array}$ & 16 & 4.43 \\
\hline $\begin{array}{l}\text { Learning community building for promoting cooperation in the } \\
\text { community and reducing social disadvantages. }\end{array}$ & 14 & 4.4 \\
\hline $\begin{array}{l}\text { Strengthening social inclusion, increasing social activity and social } \\
\text { cohesion. }\end{array}$ & 12 & 4.46 \\
\hline $\begin{array}{l}\text { Developing learners regularly supported by child welfare services, } \\
\text { disadvantaged and highly disadvantaged learners and learners living } \\
\text { with disabilities; increasing their motivation with recreational pro- } \\
\text { grams aiming at broadening their world view. }\end{array}$ & 11 & 4.41 \\
\hline $\begin{array}{l}\text { Preserving local values and the values of Hungarians, knowledge of } \\
\text { nationality traditions. }\end{array}$ & 9 & 4.39 \\
\hline $\begin{array}{l}\text { Self-knowledge and knowing others, developing social skills and } \\
\text { social relations. }\end{array}$ & 5 & 4.48 \\
\hline Developing mental health and emotional intelligence. & 4 & 4.44 \\
\hline Developing environmentally conscious behaviour. & 4.48 \\
\hline The importance of social equality. & 4.6 \\
\hline Career counselling sessions for upper-primary school students. & 4.27 \\
\hline Alcohol and drug prevention. & 1 & 4 \\
\hline
\end{tabular}

TABLE 4 Educational goals

\subsection{The birthplace of new friendships}

One of the most important features of the camps is that they contribute to children's personality development by promoting the formation of new relationships and deepening old relationship. It is also a central element of the mission and undertaking of the Erzsébet Camps. Naturally, our research also addressed how the camps performed in this respect.

Based on three years of data collection, it is found that new social relationships and friendships are a prominent added value of the camps in Zánka. The vast majority of the children, nine out of ten campers, made new friendships during the time spent in Zánka. (Figure 3) 


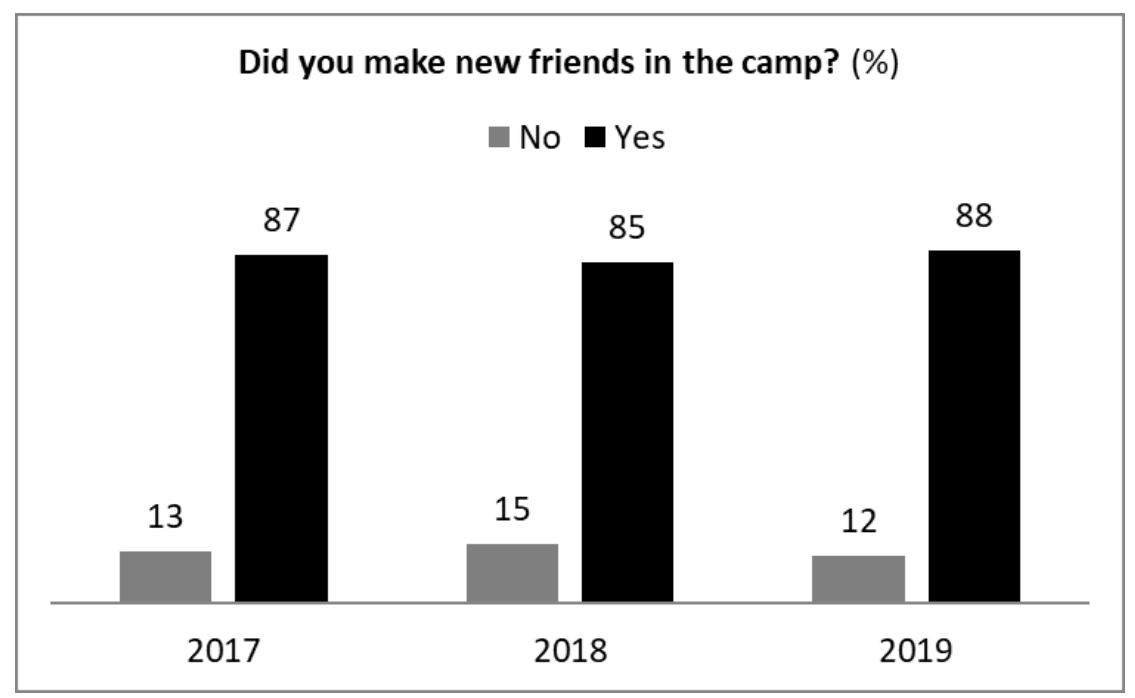

Figure 3

Among the 11,500 respondents participating in the research in 2019, girls made new friendships in a slightly higher proportion than boys.

\begin{tabular}{|l|c|c|c|}
\hline & $\mathrm{N}$ & yes (\%) & Sig. \\
\hline boys & 5131 & $86.47 \%$ & \multirow{2}{*}{ sig. $<0.05$} \\
\hline girls & 6300 & $89.76 \%$ & \\
\hline
\end{tabular}

TABLE 5

In connection with the campers' evaluations, apart from questions measuring satisfaction and eliciting evaluative feedback, we also investigated commitment towards the Erzsébet Camps. We intended to find out how many campers would be happy to participate in the camp again. It is also a sign of satisfaction if the child would be happy to revisit an Erzsébet Camp in the following year (mostly those campers say that they would participate in the camp again who were more satisfied), and if they would recommend it to their friends to participate in an Erzsébet Camp.

Our findings reveal that nine out of ten campers would like to participate in an Erzsébet Camp again. This result was not surprising given the previous positive feedback. (Figure 4) 


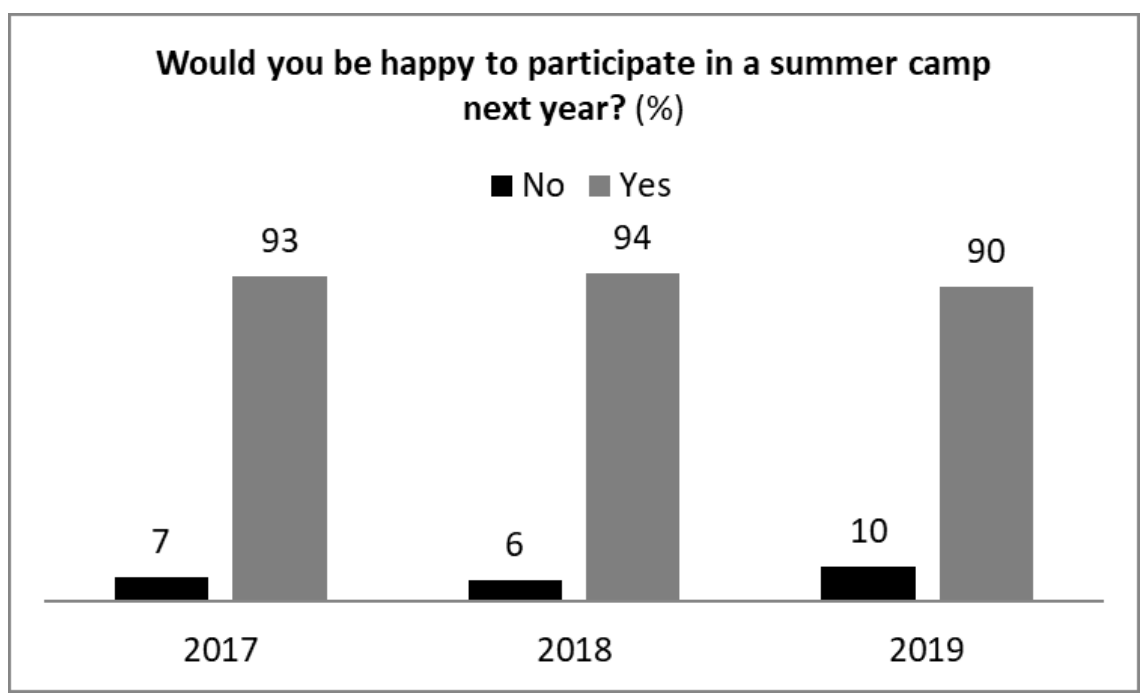

Figure 4

The campers' opinions and attitudes are not only valuable as they serve as feedback from the target audience of Erzsébet Camps but also because they may reveal what interpretations appear among peer communities about the Erzsébet Camps: its mission, the success of its undertakings in experiential education and its impact. The findings on the image of the camps being formed in indirect target groups such as peer groups are equally important for our research, as peer groups are further primary users and potential beneficiaries of this initiative. For that reason, the questionnaire contained an item on how positively or negatively the campers' experiences and opinions regarding the camps are transmitted to their peer group.

As it is revealed in the following figure (Figure 5), the campers reinforce and transmit their positive opinions concerning their "everyday" experiences in the camp to their friends, which means that they create a good reputation for the camps. This factor - due to the fact that groups formed by friendship relationships serve as an interpretative community - is important feedback, as apart from "customer satisfaction", it also refers to commitment towards the Erzsébet Camps. With reference to the item on sharing information in peer communities, girls indicated a somewhat more definite intention (Table 6), however, it is revealed that there are no significant chasms between respondents in terms of age groups (Table 7), which means that each age group would recommend the camp to their friends. 


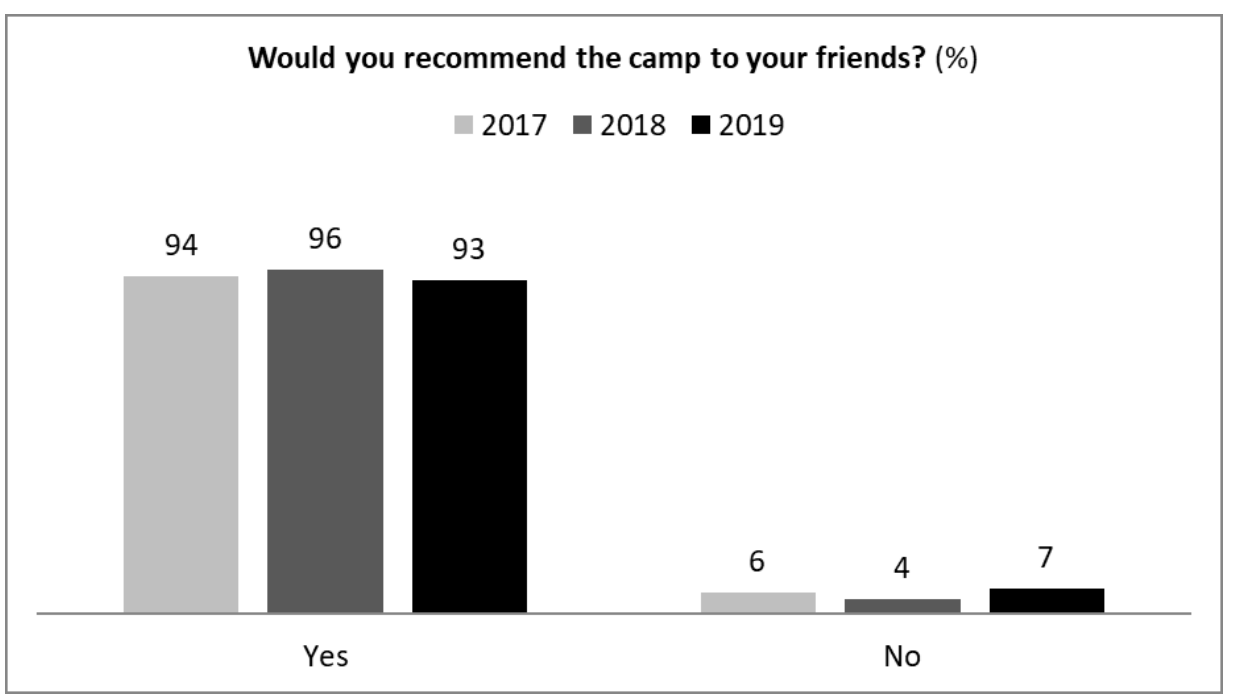

Figure 5

\begin{tabular}{|l|c|c|c|c|}
\hline gender & Mean & Yes (\%) & $\mathrm{N}$ & Sig. \\
\hline boys & 0.9 & $90 \%$ & 5131 & \multirow{2}{*}{ sig. $<0,05$} \\
\hline girls & 0.94 & $94 \%$ & 6289 & \\
\hline Total & 0.92 & $92 \%$ & 11420 & \\
\hline
\end{tabular}

TABle 6

\begin{tabular}{|c|c|c|c|}
\hline Age groups 2019 & Mean & Yes (\%) & $\mathrm{N}$ \\
\hline 10 years and younger & .93 & $93.09 \%$ & 2360 \\
\hline 11 years & .92 & $92.31 \%$ & 1937 \\
\hline 12 years & .92 & $92.23 \%$ & 2188 \\
\hline 13 years & .93 & $92.74 \%$ & 2121 \\
\hline 14 years & .93 & $92.73 \%$ & 1954 \\
\hline 15 years and older & .89 & $89.14 \%$ & 948 \\
\hline Total & .92 & $92.34 \%$ & 11508 \\
\hline
\end{tabular}

TABLE 7 


\subsection{The camps' added values to children's life}

Our research focused not only on a deeper understanding of the campers' attitudes but also on the views of teachers, who constitute the other direct target group. During our data collection among the chaperones in the winter of 2018, we administered questionnaires which had a question block asking the chaperones' views on 31 factors, intending to explore if and to what extent they may have contributed to children's development. (Figure 6) Based on the responses given on a 5-point scale, the following factors can be identified as added values to children's development: establishing relationships, cooperation skills, thinking in terms of community, rule-governed behaviour, sports and recreational skills, helpfulness, empathy, self-discipline, social competences, self-confidence, patience, emotional intelligence, taking responsibility and trust in others. More than $90 \%$ of the respondents indicated that there was development regarding the above factors (scores 4 and 5 on a 5-point scale). It is also worth noting that the respondents also underlined the developmental effects of the camps in case of another seven factors (initiative, resourcefulness, managing conflict, courage, creativity, independent thinking and democratic competences). Two thirds of the respondents identified six further factors as having a positive effect. According to the chaperones, it is the usage of ICT tools that the camps had the least developing effect on (a quarter of the respondents believe that the camp did not develop it). It is an important finding that $80 \%$ of the chaperones regarded the developmental effect of the camps to be a five with regard to establishing relationships, cooperation skills and thinking in terms of community. More than two thirds saw a similarly high level developmental effect with reference to rule-governed behaviour, recreational skills, curiosity and helpfulness. 


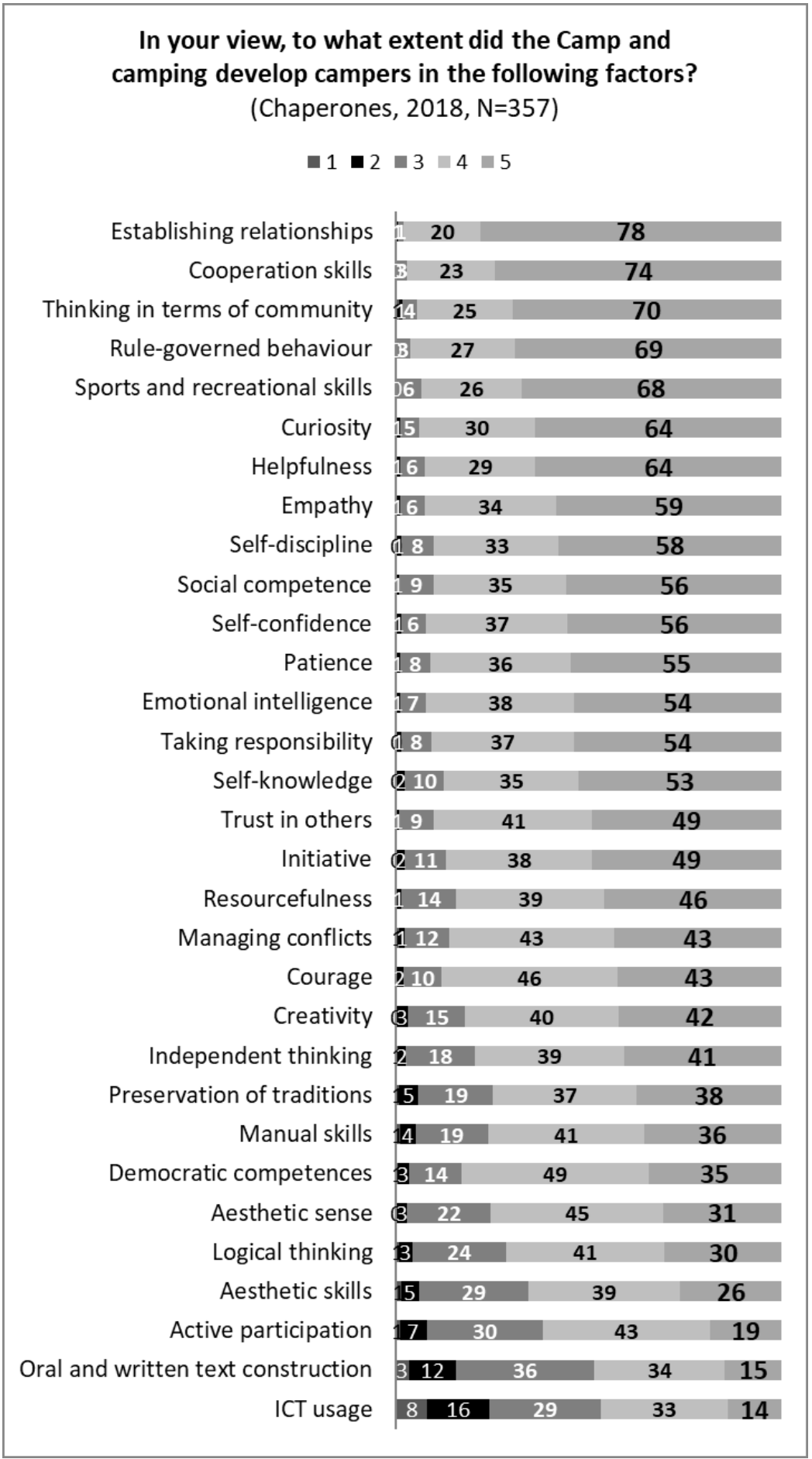

FigURE 6 
When examining the chaperones' views, we intended to find which social skills they believe to undergo value transmission processes within camping, and what deeper patterns of the world of values and transmitted value orientation in the camps can be revealed.

In accordance with the "educational credo" of the Erzsébet Camps, we selected sixteen social values and, based on their mean scores received on a 5-point scale, we established an order of value preferences. (Table 8) It was revealed that, apart from active recreation, it was humanistic values that received high mean scores as the main values transmitted by camping, such as helpfulness, security, tolerance, equality, true friendship, respect for others, being free from prejudices and solidarity. It is important to note that some of these belong among traditional social values (helpfulness, security, equality, true friendship, respect and solidarity), which are transmitted in a trans-historical way, i.e. over several eras, from one generation to another, and as a result, are part of our culture and manifest their effects over generations. Active recreation, tolerance and being free from prejudices are so-called post-material social values, which are part of the value orientations of the $21^{\text {st }}$ century. Our data suggest that value transmission processes that take place in the course of realising educational programmes in the Erzsébet Camps support family socialisation effectively.

\begin{tabular}{|l|r|}
\hline active recreation & 4.73 \\
\hline helpfulness & 4.62 \\
\hline security & 4.59 \\
\hline tolerance & 4.55 \\
\hline equality & 4.54 \\
\hline true friendship & 4.52 \\
\hline respect for others & 4.52 \\
\hline being free from prejudices & 4.49 \\
\hline solidarity & 4.49 \\
\hline respecting community property & 4.48 \\
\hline courage & 4.45 \\
\hline physical and mental health & 4.44 \\
\hline politeness & 4.44 \\
\hline honesty & 4.41 \\
\hline joy of a job completed & 4.37 \\
\hline conscientiousness & 4.30 \\
\hline
\end{tabular}

TABLE 8: In your view, to what extent did the Camp transmit the following social values towards campers? (2018 winter follow-up study, mean scores on 5-point scale, $N=357$ )

In the winter of 2018, we administered an online survey among the chaperones who had participated in summer camps before. We inquired about the developmental effect of the camps with respect to six overall factors that were crucially important from the perspective of the camps. Analysing our data (Table 9), we found that more than $80 \%$ of the 329 teachers working as chaperones gave a score of 4 or 5 on a 5-point scale with respect to all the six factors, which suggests that developing these factors was part of the educational goals realised in the camps. 
Observing the mean scores, we can see that there is a difference of only .6 between the highest mean score (4.7) for the development of social competences and the lowest mean score (4.1) for developing independent thinking. It is to be highlighted that the opinions formed in the chaperones reflect that the Erzsébet Camps' undertaking to realise educational goals in its programme beyond just providing the traditional framework for a water summer camp holiday was successfully achieved. With respect to areas of non-formal educational, it is found that the chaperones evaluated community building (mean score: 4.8 ), and the realisation of sports and recreational activities (4.6) to be excellent, furthermore, preservation of traditions (4.1) and artistic education (3.9), seen as further missions of the camps, also received high scores. (Table 10)

\begin{tabular}{|l|c|c|c|c|c|}
\hline & 1 & 2 & 3 & 4 & 5 \\
\hline Developing social competences & 0.2 & 0.6 & 3.5 & 18.6 & 77,2 \\
\hline Developing emotional intelligence & & 1.1 & 6.7 & 38.4 & 53,8 \\
\hline Developing conflict management & 0.8 & 1.4 & 11.5 & 42.9 & 43,4 \\
\hline Developing independent thinking & 0.6 & 2 & 17.9 & 38.7 & 40,9 \\
\hline Developing in terms of community & 0.8 & 0.8 & 3.9 & 24.6 & 69,7 \\
\hline Developing self-knowledge & 0.3 & 2 & 10.1 & 35 & 52,7 \\
\hline
\end{tabular}

TABLE 9 Chaperones 'views on the developmental effects of Erzsébet Camps (2018 winter follow-up study, mean scores on 5-point scale, \%)

\begin{tabular}{|l|c|c|c|c|c|}
\hline & 1 & 2 & 3 & 4 & 5 \\
\hline Community and team building & 0.2 & 0.6 & 2.4 & 12.9 & 83.9 \\
\hline Sports and recreation & & 0.3 & 6.2 & 26.1 & 67.5 \\
\hline Preserving traditions and values of the Hungarians & 0.8 & 5 & 19.3 & 37.3 & 37.5 \\
\hline Artistic education & 1.4 & 4.5 & 28.6 & 39.2 & 26.3 \\
\hline
\end{tabular}

TABLE 10 Chaperones' views on the developmental effects of Erzsébet Camps (2018 winter follow-up study, mean scores on 5-point scale, \%)

When surveying chaperones, we also intended to explore their self-reflections regarding their "take away" from the camps. In their evaluation, did the camps contribute to the foundations of their professional work and educational repertoire? $79 \%$ of the more than 1,400 respondents in the 2019 summer camps said that they had specific educational goals with participating in the camps. In this context, it is important feedback that nearly two thirds of the chaperones expressed that the camps provided help and support in performing their work more effectively outside the camps. (Figure 7) These responses reinforce our claim that the Camps can form chaperones' educational-methodological tools and professional skills considerably. The findings refer to long-term effects of the camps as well, especially because the vast majority of the chaperones' institutes had specific educational goals with the camps ( $74 \%$ gave this response) and chaperones themselves also had this "initial" goal (79\%). The dissemination of experiences 
planned by chaperones (Table 11) can create space for supporting the educational functions of institutes and family socialisation, but also for forming children's peer groups.

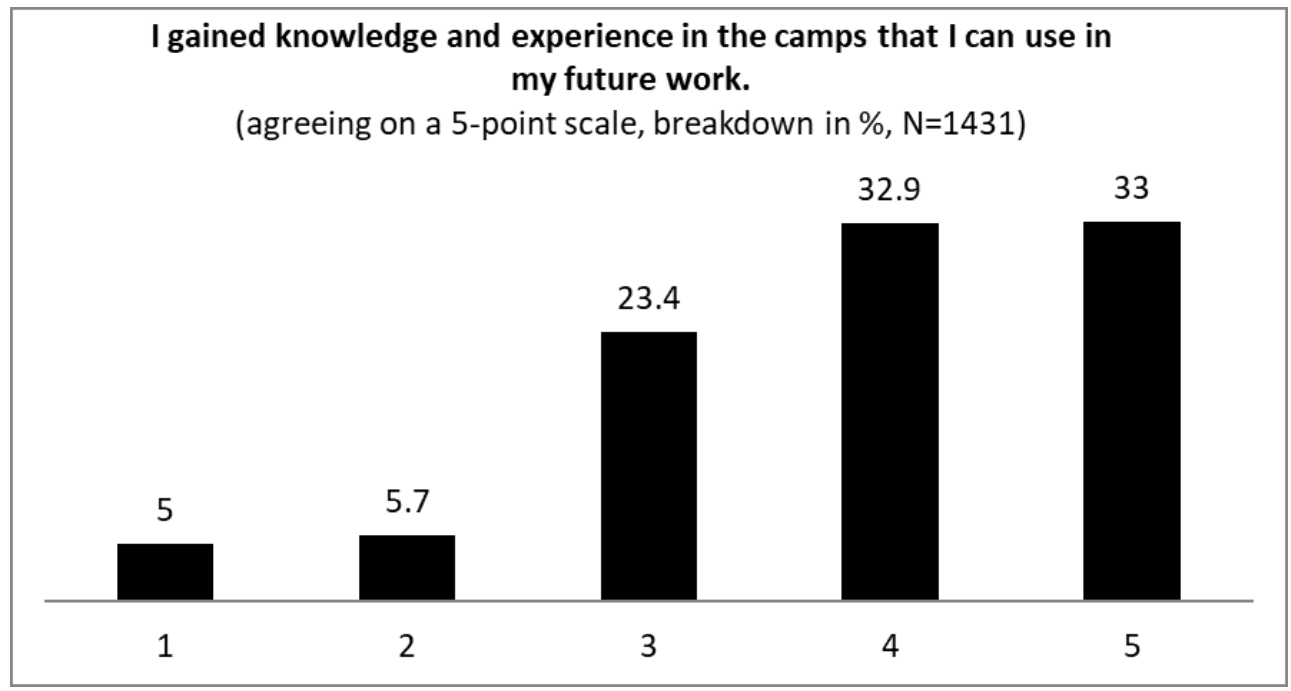

Figure 7

\begin{tabular}{|l|l|}
\hline with institute heads & 71 \\
\hline with colleagues & 86 \\
\hline with parents & 85 \\
\hline with children, students & 81 \\
\hline
\end{tabular}

TABLE 11 Are you planning to share your camping experiences? (yes responses, \%)

Chaperons views, as presented above, which express appreciation for experiential knowledge that can be applied in their everyday practice, were shed even more light (Figure 8) on when the vast majority of respondents revealed in the relevant sections of the questionnaire that the camps had contributed to their relationships with children developing positively. 


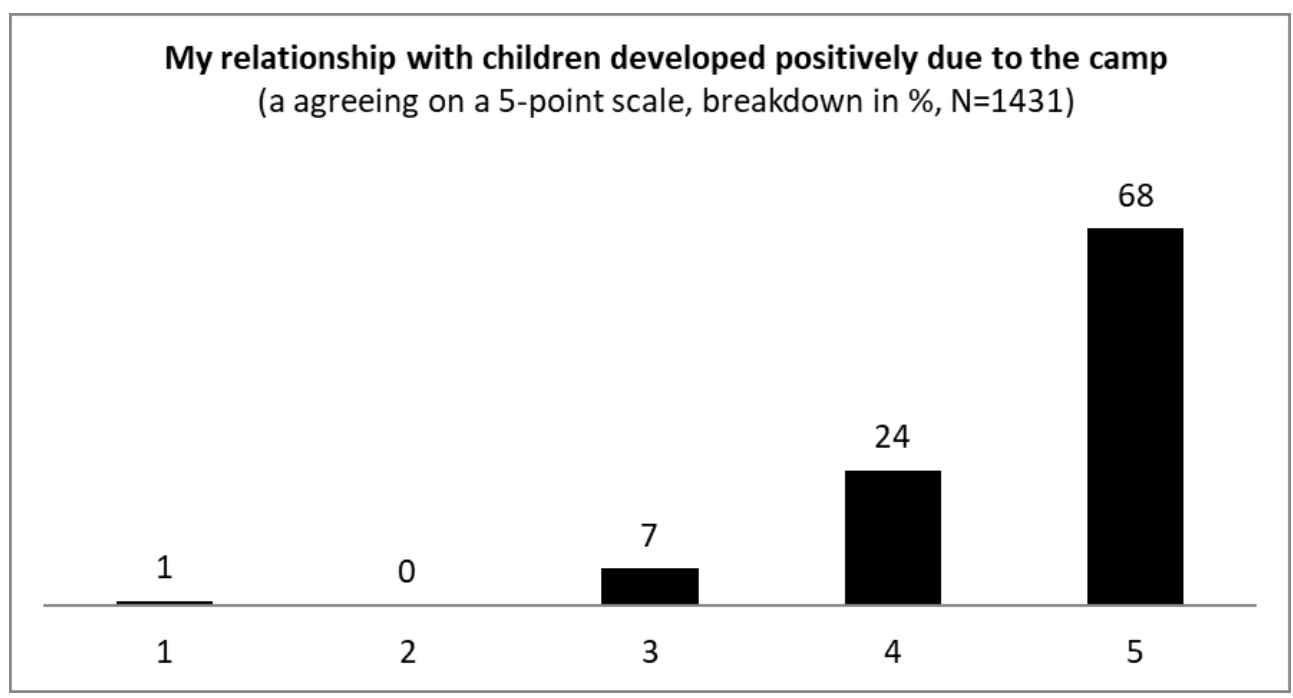

Figure 8

\section{SUMMARY}

Our research, exploratory in its nature, set out to compile the "value map" of the Erzsébet Camps. The main focus of our interest was the added value and developmental effects of the camps with respect to campers. Another research question was what social values are transmitted and the preservation of which social values is supported by the Erzsébet Camps. The present study conducted analyses on a database compiled from findings of questionnaires administered to campers (2017, 2018 and 2019) and their chaperones (2018 and 2019). Based on our results, the following conclusions can be drawn. The main developmental effects of the Erzsébet Camps are realised in the development of community and social competences, and in the area of emotional intelligence. Furthermore, the camps' undertaking to develop sports and recreational skills is also achieved effectively. Organizing events that are rooted in experiential pedagogy and coordinating educational goals and tools for achieving them support the systematic and conscious personality development goals of the camps. The world of values transmitted by the Erzsébet Camps constitute traditional humanistic social values, which are identical with the value orientations of the Judeo-Christian culture. The Erzsébet Camps represent a considerable added value to children's emotional, cognitive and ethical education, furthermore, they support the realisation of social functions. Based on the above, we can claim that the institution of Erzsébet Camps represents and realises value-saturated recreational education. 


\section{REFERENCES:}

Baden-Powell, Robert (1908): Scouting for Boys. A Handbook for Instruction in Good Citizenship. London.

Baden-Powell, Robert (1992): A cserkészvezetö. Budapest, Magyar Cserkészcsapatok Szövetsége. https:/www.96solyom.hu/wp-content/uploads/2011/10/B.P.-A-cserk\%C3\%A9 szvezet\%C3\%B6.pdf Utolsó letöltés: 2020.06.05.

BÁNHIDI, AtTILA (szerk.) (2004): Vándortáborozási kézikönyv. Budapest, Mobilitás.

BoDor, TAMÁs (2006): Táborszervezés, táborvezetés. Ifjúságsegitőknek és érdeklödőknek. Szombathely, Megyei Müvelődési és Ifjúsági Központ.

Dorka, PÉTer: Táborozás célja, feladatai. http://www.jgypk.hu/tamop13e/tananyag_html/ tananyag_reki_1/vi15_tborozs_clja_feladata.html Utolsó letöltés: 2020.06.07.

Heimann, Ilona (2006): A táborozás. In Heimann, Ilona - Lénárd, Sándor - Mészáros, György - Rapos, Nóra - Trencsényi, László: Iskolán kívüli nevelés - A gyakorlati pedagógia néhány alapkérdése. Budapest, ELTE. http://mek.niif.hu/05400/05462/05462.pdf Utolsó letöltés: 2020.06.07.

MaJZIK, VALÉRIA (1997): Summerhill - mit kezdjünk vele? Iskolakultúra 7. évf. 1. sz. 17-20.

MANDÁk, Csaba (2010): Táborok - intézményesült ifjúságsegítői szolgáltatásformák. In Földi, László - Nagy, Ádám (szerk.): Ifjúságügy, ifjúsági szakma, ifjúsági munka módszertani kézikönyv. Budapest, Mobilitás - Új Mandátum - Excenter.

NAGY, ÁDÁM (2018): A táborozáspedagógia és helye a pedagógiai rendszertanban - A hidden extracurriculum körvonalai. Új Pedagógiai Szemle. /5-6. sz. 60-86. http://real.mtak.hu/83963/1/ UPSZ_2018_5_6_tordelt_09_13_u.pdf

NAGY, ÁDÁm (szerk.) (2018): A komfortzónán is túl. A táborozás pedagógiája, szociológiája és kulturális antropológiája. Kecskemét, NJE- ISZT.

SíK, SÁNDOR (1992): Magyar cserkészvezetők könyve. 1.,2. Budapest, Márton Áron Kiadó.

Solymosi, Balázs (et.al.): Egységes Ifjúságnevelési kézikönyv. Budapest, Magyar Cserkészszövetség. $\quad$ https://www.cserkesz.hu/sites/default/files/2020-04/Egyse\%CC\%81 ges $\% 20$ ifju $\%$ CC $\% 81$ sa $\%$ CC $\% 81$ gnevele $\%$ CC $\% 81$ si $\% 20$ koncepcio $\%$ CC $\% 81$.pdf Utolsó letöltés: 2020.06 .05 .

TRENCsÉnYI, LÁsZló (2018) Hadiösvények és békepipa. Táborozástörténet 1919-töl napjainkig. In Nagy Ádám (szerk.): A komfortzónán is túl. A táborozás pedagógiája, szociológiája és kulturális antropológiája. Kecskemét, NJE-ISZT. 212-232. 